\title{
Using the Arts to Foster Students' Interest, Engagement, and Learning in a Distance- Learning Environment
}

João Alberto Arantes do Amaral

Prof., corresponding author, Federal University of São Paulo, Brazil, jarantes@alum.mit.edu

Suzana Costa Brito

Federal University of São Paulo, Brazil, suzanacbrito@outlook.com

\begin{abstract}
In this article, we discuss the lessons learned in a system thinking course developed in a multicampus, distance-learning environment. Forty-six undergraduate students were involved; the students were from four campuses of the Federal University of São Paulo, Brazil. We explain the course design, curriculum and online components. We analyze the effectiveness of the use of art (visual art, literature, performing arts and media arts) in fostering the students' interest, engagement and learning. In order to gather data, we used a convergent parallel mixed method approach. We made systemic analysis of the data collected. We found that the use of music, poetry, stories and films helped students to make connections between theory and practice, thereby improving their learning. Students' use of these materials also increased their enthusiasm for the course. We also found that the visual arts, in particular, fostered the students' curiosity, increasing their engagement in the proposed activities.
\end{abstract}

Keywords: arts, multi-campus, distance learning environment, project-based learning, systemic analysis

\section{INTRODUCTION}

In this article, we discuss the lessons learned about the integration of the arts in a course developed in a multi-campus, distance-learning environment. The course, entitled "Systems Thinking," followed a project-based learning (thereafter PBL) approach. It was delivered to 46 students from four different campuses of the Federal University of São Paulo (thereafter UNIFESP).

The course began in March and ended by the middle of June 2017. The aims of the course were to teach the students the basic concepts of systems thinking and to develop their modeling skills so as to be able to apply systems thinking concepts within their fields of expertise. For example, a student of medicine should be able to use the concepts studied in order to create models of the interactions between human body systems; a student of engineering should be able model the dynamics present in industrial systems; and a student of social sciences should be able to model interventions in social systems. The course therefore should be broad enough to be useful to students of different backgrounds. At the end of the course each student was required to deliver an individual project, a short case study related to their field of expertise. The case study would discuss a systemic problem in the student's field and present a system dynamics model (causal loop diagram) that represents the dynamics present in the problem.

In order to facilitate the learning, we developed a virtual learning environment, where we made available the textbook and several other art-related materials. We challenged the students to read, every week, a book chapter or perform modeling activities based on the book's case studies. In order

Citation: Arantes do Amaral, J. A., \& Brito, S. C. (2018). Using the Arts to Foster Students' Interest, Engagement, and Learning in a Distance-Learning Environment. Anatolian Journal of Education, 3(2), 1-18. https://doi.org/10.29333/aje.2018.321a 
to foster the students' interest, learning and engagement, we made extensive use of art (visual art, literature, performing arts and media arts).

Our research question thus became: "How effective is the use of the arts in fostering the students' interest, engagement and learning in PBL-centered courses, accomplished in distance-learning environments?" In this article, we present our findings related to the research question.

\section{Literature Review}

In this article, we discuss the use of arts in order to enhance student' experience. We do not intend to discuss the usage of all forms of art; we will describe our experience using an example of each type of art. For example, when we refer the use of visual arts, we focus on use of cartoons and comic strips; when we mention literature we focus on poetry, stories, newspaper articles and case studies; when we discuss performing arts, we focus on music; when we talk about media arts we focus on documentaries and films.

The textbook we followed is a cartoon-illustrated book. Cartoon-illustrated books have been developed in many fields, including statistics (Gonick \& Smith, 1993; Takahashi, 2008), algebra (Gonick, 2015; Takahashi \& Inoue, 2012), physics (Gonick \& Huffman, 1991; Nitta \& Takatsu, 2009), genetics (Gonick \& Wheelis, 1991), environmental sciences (Bauman \& Klein, 2014; Gonick \& Outwater, 1996), calculus (Gonick, 2012), economics (Bauman et al., 2011; Bauman \& Klein 2010). Scholars point out that use of comics as teaching material can bring educational benefits (Tatalovic, 2009) such as facilitating learning (Richie, 1979), arousing students' curiosity and engagement (Hall, 2005; Ramos \& Vergueiro, 2013) and stimulating critical thinking and reflection (Decker \& Castro, 2012; Richie, 1979). Scholars (Scanlan \& Feinberg, 2000) have also noted that comics can be a very effective way to help students make connections between theory and real-world situations.

The textbook we adopted also included case studies. Researchers point that case studies can be used to help the students to understand complex situations (Kunselman \& Johnson, 2004), to make connections between theory and practice (Mayo, 2004), to develop critical thinking (Popil, 2011) and to develop problem solving skills (Jonassen \& Hernandez-Serrano, 2002).

In relation to literary material, we used newspaper articles, stories, poetry and case studies. Scholars have noted that newspaper articles can expand student understanding and also bring real-world examples to the classroom (Mysliwiec et al., 2003). Other researcher (Watson, 2003) point that stories can help to make intangible concepts concrete, fixing the contents in the students' minds and inspiring them to act in an ethical way. More than that, scholars (Jonassen \& Hernandez-Serrano, 2002) point out that stories can be a very useful way of supporting problem-based learning courses, since stories can be used as a source of empirical learning. Regarding poetry, researchers point out that the use of poetry in classroom may contribute to the development of the students' emotional intelligence (Morris et al., 2005), increase their motivation (Çetinavcı \& Tütüniş, 2012) and promote self-reflection (Charon et al., 1995; Freeman \& Bays, 2007).

In relation to performing arts, we used music. Scholars note that songs can be an useful tool in improving comprehension (Hall \& Lawson, 2008) and learning (Tinari \& Khandke, 2000).

In relation to the media arts that we used (documentaries and films), scholars point out that documentaries can be very useful to exemplify real-life issues, problematic situations and to contextualize ideas (Leet \& Houser, 2003). More than that, documentaries can facilitate the learning of concepts and theories (Bumpus, 2005), and can be used to analyze complex issues from different points of view (Marcus \& Stoddard, 2009). 
In our research, we focus on the use of art in a PBL course, developed in a distance-learning environment. In recent years, scholars have studied different arrangements in order to create enjoyable and creative project-based learning environments (Arantes do Amaral et al., 2015). Some researchers reported the use of music to stimulate creativity and develop group cohesion (Lindvang \& Beck, 2015). Other scholars explored the use of plays to enhance collaboration and learning (Thorsted et al., 2015). Still others report the use of grouping drawing activities in order to facilitate the understanding of complex problems (Arantes do Amaral et al., 2017).

Although there is a reasonable number of articles that describe the use of single art activities in PBL learning environments, it seems that there is still a lack of information about the combined use of different expressions of art (visual art, literature, performing arts and media arts) in PBL-centered courses in distance learning environments. In our research, we aim to address this gap.

\section{METHOD}

In our research, we followed a convergent parallel mixed method approach (Creswell, 2013). In this approach, quantitative and qualitative data are unified in order to provide a better understanding of the problem analyzed (Curry \& Nunez-Smith, 2014). Researchers point out the benefits of mixed methods approaches, which combine the strengths of qualitative and quantitative analysis, reducing the weakness of both and enlarging the extensiveness of the research (Driscoll et al., 2007).

\section{Data gathering procedures}

We collected data from questionnaires that we sent to the students at the week before the end of the course. The questionnaires had nineteen queries: three pairs of queries about the learning environment (APPENDIX 1), six pairs of queries about the students' perceptions about the role of the arts in facilitating the learning (APPENDIX 2) and one open-ended question about the students' perspectives on the course (APPENDIX 3).

In each pair of queries, the first was closed-ended statement, and the students were asked to agree or disagree using the Likert scale. The second question was open-ended and was designed in order to give us a deeper understanding of the students' answers to the first statement.

The quantitative data was collected from the answers to the close-ended statements; the qualitative data was collected from the answers to the open-ended questions.

\section{Population}

There were 46 undergraduate students from the majors of health science, science and technology, environment sciences and philosophy, languages and human science, from four different campuses of UNIFESP, located in four different cities of Sao Paulo state, Brazil (Table 1).

Table 1

The four Campuses and the courses offered in each one

\begin{tabular}{ll}
\hline Campus & Undergraduate Courses offered \\
\hline Unifesp Sao Paulo & $\begin{array}{l}\text { Courses related to health sciences (Medicine, Nursery, Information Technology in Health, } \\
\text { Radiology Technology, Ophthalmic Technology, Biological Sciences) } \\
\text { Courses related to Science and Technology (Computation Engineering, Materials Engineering, }\end{array}$ \\
$\begin{array}{l}\text { Unifesp Sao José dos } \\
\text { Campos }\end{array}$ & $\begin{array}{l}\text { Biotechnology, Computational Mathematics, Biomedical Engineering) } \\
\text { Courses related to Environmental Sciences, Chemistry and Pharmacy (Environmental Sciences, } \\
\text { Unifesp Diadema } \\
\text { Biological Sciences, Chemical Engineering, Chemistry, Industrial Chemistry, Pharmacy) } \\
\text { Unifesp Guarulhos } \\
\text { Courses related to Philosophy, Languages and Human Sciences (Social Sciences, History, History } \\
\text { of Art, Philosophy, Pedagogy) }\end{array}$ \\
\hline
\end{tabular}




\section{Data analysis}

We analyzed the quantitative data by means of descriptive statistics and the qualitative data by means of the language process method (Graham, Shiba, \& Walden, 2001). The language process method was applied in order to organize the qualitative data in the form of recurrent theme categories (Renner \& Taylor-Powell, 2003; Yin, 2015). After that we connected the two forms of data by means of systemic analysis (Arantes do Amaral \& Frazão, 2016). In so doing, we were able to unify the data and have a better understanding of the consequences of the actions we took during the course, unveiling the systemic aspects of it.

Validity and reliability

The validity was assured by means of triangulation (Creswell, 2013) since we collected quantitative and qualitative data from students from four different campus. More than that, the quantitative and qualitative data reinforced each other. The content validity was assured since the quantitative and qualitative data was obtained from all elements of the population (all students answered the questionnaires), we did not work with samples.

The reliability was assured by the correctness of our research approach (Creswell, 2013), since we followed a coherent approach, with precise and detailed phases, allowing other scholars to follow similar procedures if they wish.

The course conception and development

The course followed a project-based learning approach, with clearly defined goals and deliverables. We designed the course in the following way:

- During the five initial weeks, the students would learn the basic concepts of systems thinking theory and modeling tools. Each week, we would ask the students to read a book chapter and read and watch the art material related to this chapter (one poem, one story, one newspaper article, one song, one movie).

- In each of the following seven weeks, we would ask the students to read one book's case study and do the case study's modeling exercise. In addition, we would ask the students to read and watch the art material related to the case study.

- In the following four weeks, we would give the students guidance about creating the individual project (a two-page case study and a causal loop diagram that would summarize the case created). In the final week of the course each student would deliver us his/her case study.

The course website

As this course was developed in a distance learning environment, we needed to create a website that would support the course. In order to facilitate the students' learning and enhance participation, we incorporated art: each week of the course was represented on one page that featured a comic strip related to the subject of the week with links to recommended readings in system thinking and beyond (Figure 1). 


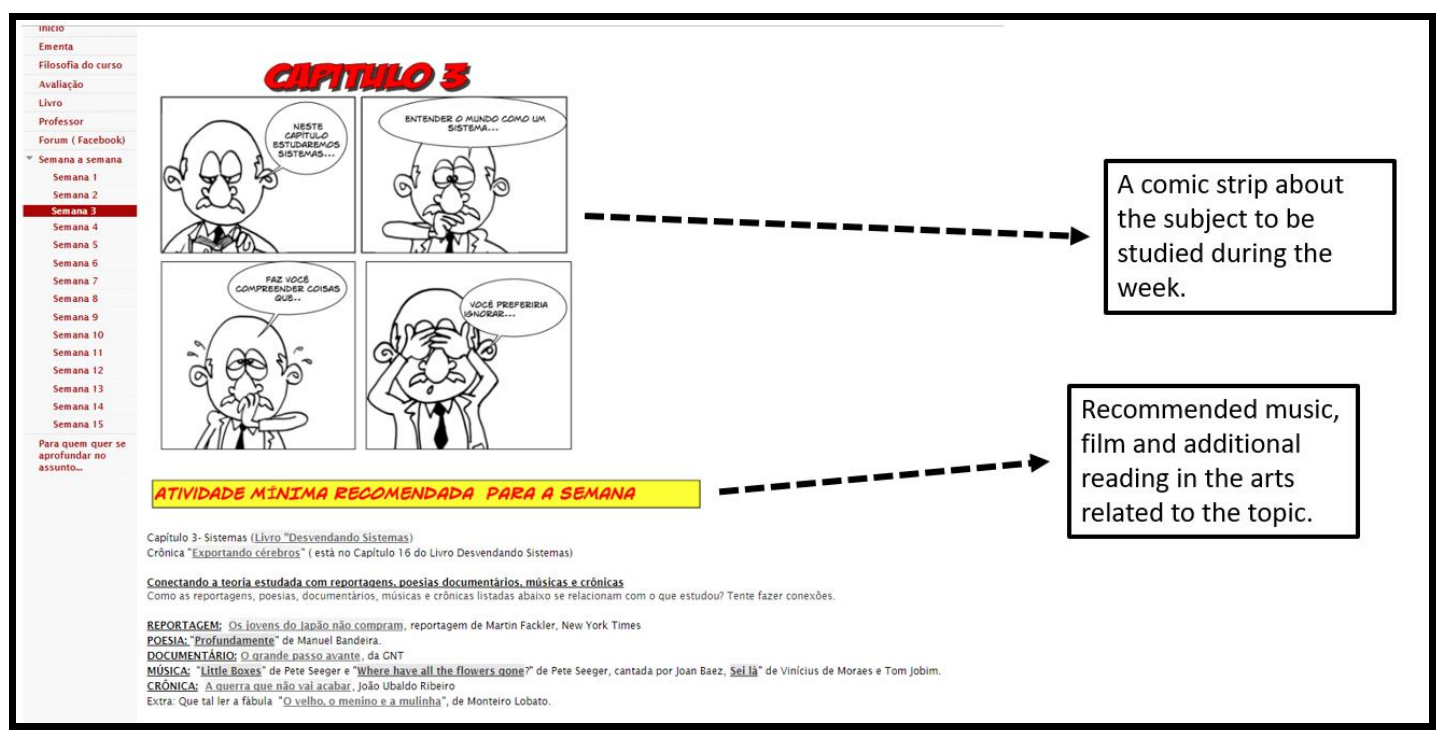

Figure 1

The webpage created for the third week of the course

Our goal in incorporating art material into the course website was to help the students make connections between theory and real-world situations. For example, in week three we asked the students to read the chapter 'Mental Models'. In order to illustrate the concept of mental models, we asked them to listen Peter Seeger's song, 'Where Have All the Flowers Gone?'. We challenged the students to try to establish connections between the meaning of the song and content of the book chapter. We proceeded in the same way with all other material selected for the week.

Our criteria for selecting the art material for the course was the following:

1. The material should be closely related to the topic of the week.

2. The material should be created by a well-known artist.

3. The material should be interesting.

4. The material should be in Portuguese, ideally.

We selected poems of from the greatest Portuguese language poets, such as Camões and Fernando Pessoa. We chose songs from well-known Brazilian compositors such as Chico Buarque and Vinicius de Moraes and stories from respected Brazilian writers such as João Ubaldo Ribeiro, Monteiro Lobato and Ferreira Gullar. We also selected material in English, such as songs of Peter Seeger and Leonard Cohen and we used documentaries such as 'Food Inc.', 'An Inconvenient Truth' and 'The Story of Stuff'. We also made available interviews of systems thinking experts such as Peter Senge and Dennis Meadows.

\section{The reference book}

The textbook was a systems thinking cartoon-illustrated book (Arantes do Amaral, 2012); each page (Figure 2) includes (an illustration, a comic strip, a caricature or a cartoon) that complements the text. 


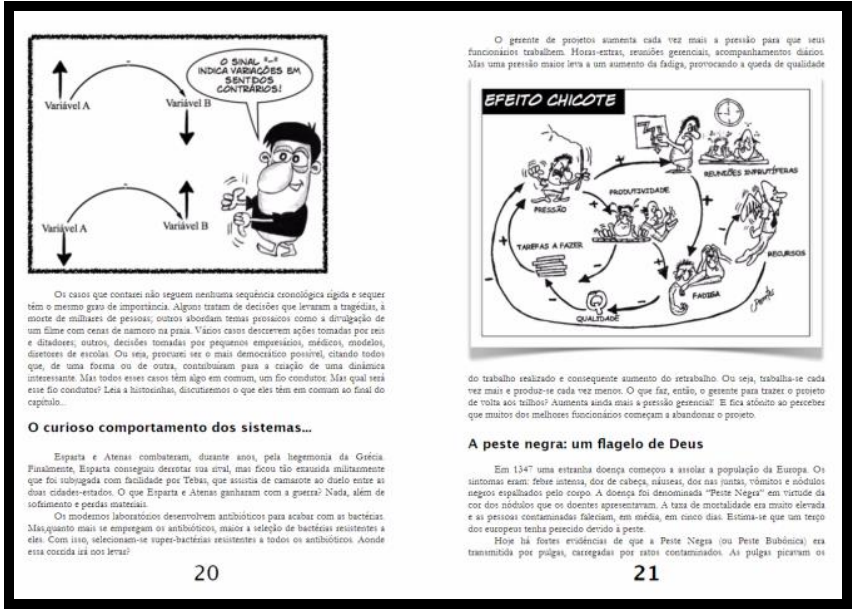

Figure 2

Pages from the textbook

The book contains several case studies. The case studies were designed for developing the student's ability to create system dynamics models. For example, Figure 3 shows a typical case study about the topic 'Global Warming'. The case describes the main dynamics responsible for global warming with the key variables in bold letters. At the end of the case study the student is asked to create a model based on the text, using the key variables as reference.

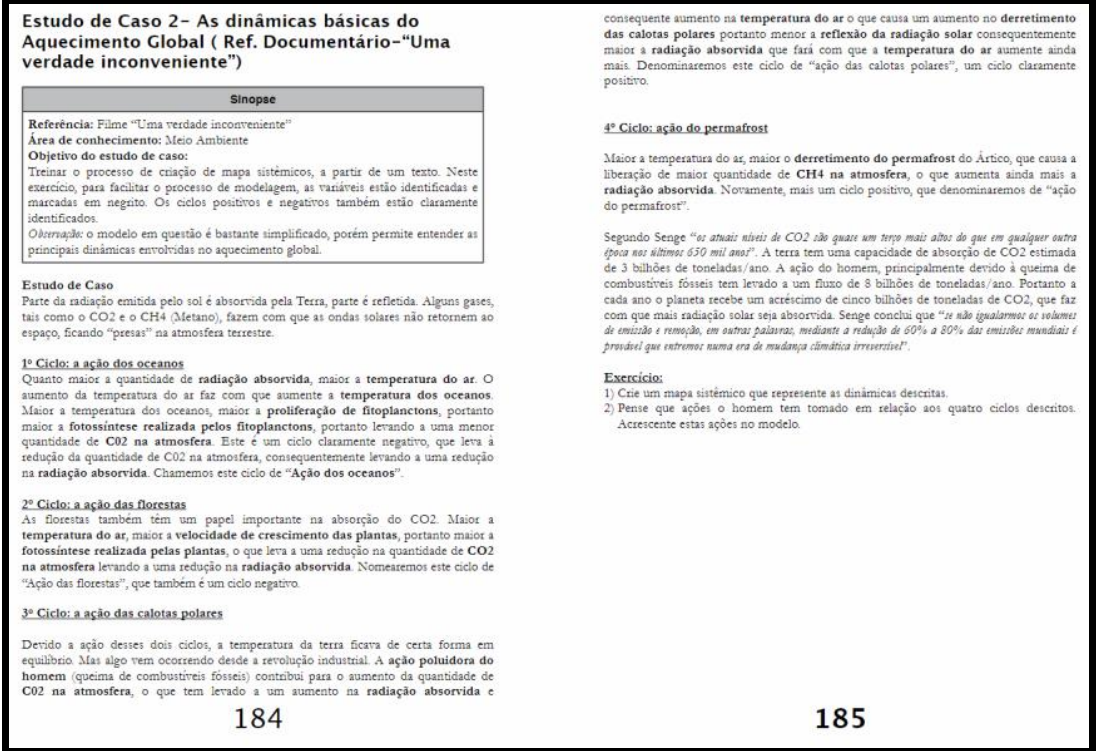

Figure 3

An example of a case study from the textbook. In this case study four dynamics related to global warming are described: the dynamics of oceans, forests, permafrost, the the polar ice cap.

The book also shows solutions to each case study (Figure 4), allowing the students to compare the models they created with the solution proposed by the book's author. 


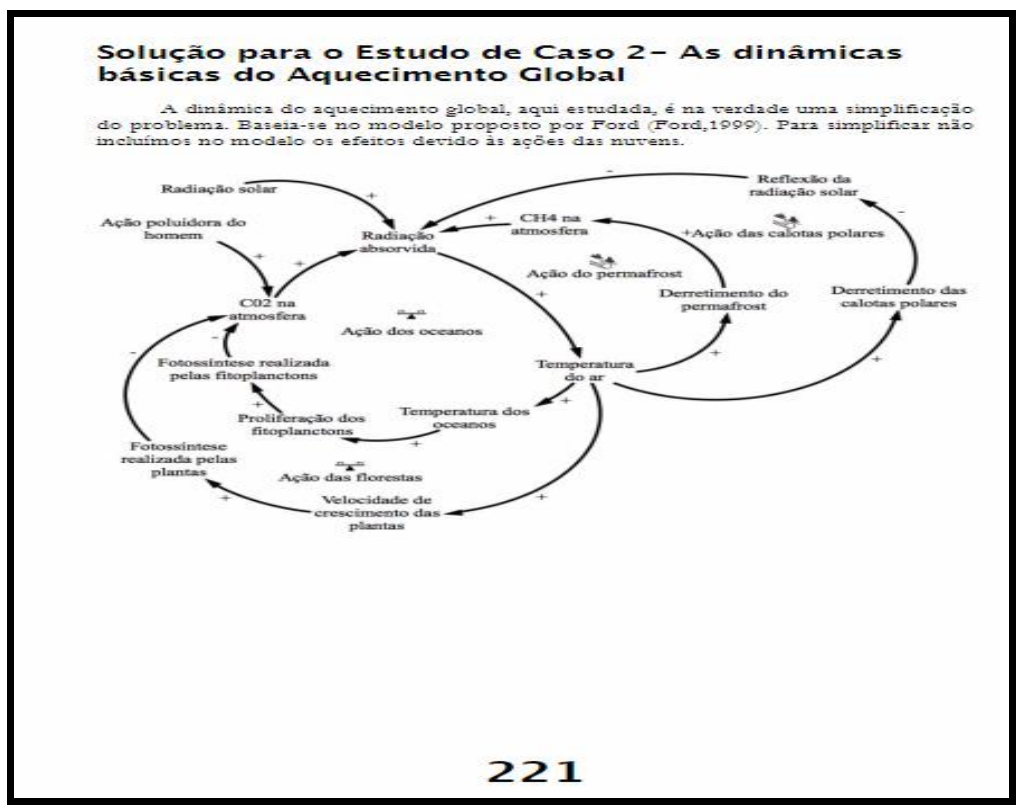

Figure 4

An example of the solution presented for the case study in the textbook. This example shows the model, a causal loop diagram that represents the four dynamics of global warming.

\section{Course development}

The course was developed in fifteen weeks, from March to June of 2017. Every week, the first author (the course professor) sent an email to all students, asking them to perform the activities defined for the week in the course website. The professor used a private Facebook's forum to answer the students' questions. In weeks two, five, ten and thirteen the professor sent quizzes and surveys to the students. The quizzes and surveys aimed to verify the students' progress and to identify the problems they were facing. In the fourteenth week of the course, the professor sent a questionnaire to the students, in order to gather data about the efficiency of the use of art material in the course. In the fifteenth week, the students sent to professor their projects.

\section{FINDINGS}

In this section, we presented the results achieved by analyzing the quantitative data by means of descriptive statistics, and the recurrent themes that emerged from the application of the language process method to the answers to questions related to the following:

1. The learning environment and textbook.

2. The connection between theory and real life.

3. The students' perspective about the combined use of all forms of art.

We also present data related to the case studies created by the students.

Results from quantitative analysis

Table 2

Brings the results obtained applying descriptive statistics to the responses to the close-ended statements about the how the book, website and art material facilitated the learning. 
Table 2

The results from quantitative analysis

\begin{tabular}{|c|c|c|c|c|c|}
\hline Statements & $\begin{array}{l}\square \text { Strongly } \\
\text { agree }\end{array}$ & $\square$ Agree & 口Neutral & 口Disagree & $\begin{array}{l}\square \text { Strongly } \\
\text { disagree }\end{array}$ \\
\hline S1.-The textbook helped your learning. & $94 \%$ & $6 \%$ & 0 & 0 & 0 \\
\hline S.2-The supportive website helped your learning. & $80 \%$ & $18 \%$ & $2 \%$ & 0 & 0 \\
\hline $\begin{array}{l}\text { S.3-The website's comic strips and the cartoons } \\
\text { helped your learning. }\end{array}$ & $72 \%$ & $22 \%$ & $2 \%$ & $2 \%$ & $2 \%$ \\
\hline $\begin{array}{l}\text { S.4-The newspaper reports helped you to make } \\
\text { connections between the theory and real-life } \\
\text { problems. }\end{array}$ & $61 \%$ & $26 \%$ & $13 \%$ & 0 & 0 \\
\hline $\begin{array}{l}\text { S.5-The videos (documentaries, interviews and } \\
\text { speeches) helped you to make connections between } \\
\text { the theory and real-life problems. }\end{array}$ & $60 \%$ & $25 \%$ & $15 \%$ & 0 & 0 \\
\hline $\begin{array}{l}\text { S.6-The poetry helped you to make connections } \\
\text { between the theory and real-life problems. }\end{array}$ & $30 \%$ & $33 \%$ & $30 \%$ & $7 \%$ & 0 \\
\hline $\begin{array}{l}\text { S.7-The songs helped you to make connections } \\
\text { between the theory and real-life problems. }\end{array}$ & $37 \%$ & $35 \%$ & $24 \%$ & $2 \%$ & $2 \%$ \\
\hline $\begin{array}{l}\text { S.8-The stories helped you to make connections } \\
\text { between the theory and real-life problems. } \\
\text { S.9-The case studies helped you to make connections }\end{array}$ & $74 \%$ & $13 \%$ & $13 \%$ & 0 & 0 \\
\hline between the theory and real-life problems. & $69 \%$ & $28 \%$ & $3 \%$ & 0 & 0 \\
\hline
\end{tabular}

Analyzing the students' answers to Q1 we found that students liked the book organization, the stories told, the language style, the book's comics and cartoons and the case studies. According to one student:

"The book was very didactic: it has several examples, the author uses a language easy to follow, the illustrations facilitate the comprehension"

Another student stressed the importance of the illustrations in helping to fix the content:

"I liked it very much! The book is written in clearly, in easy-to-follow language. The illustrations were funny; they helped us to fix the content".

This led us to the first recurrent theme:

RT1- The cartoon-illustrated book aroused interest and facilitated comprehension.

Examining the answers to Q2, we learned that students found the website well organized, with interesting content, and that it was easy to access by different platforms (smart phones, computers, tablets). One student stated:

"The website is easy to access, the interface is simple, facilitating the access to the course materials".

In addition to that, another student observed:

"Everything is organized in a way that facilitated the navigation, the website brings detailed explanation about the activities that should be accomplished by the students".

The analysis of the answers to Q2 led us to our second recurrent theme:

RT2- The well-organized website facilitated finding the course's material.

Q3 let us know that students felt the comics and cartoons were fun and complementary to the text, that they aroused the students' curiosity and interest in the issues raised by the text, helped students to review the main topics, and facilitated comprehension. According to one student: 
"I think the comics and cartoons are wonderful. They fit very well with the text and arouse interest in the subject studied".

Another student commented:

"Super-cool! The cartoons turn something arid in something tasteful. It is like a delicious sauce over the spaghetti!".

The analysis of the answers to the Q3 led us to our third recurrent theme:

RT3- The comic strips and the cartoons facilitated comprehension and aroused the students' interest and curiosity.

Their answers to Q4 let us know that the newspaper articles helped them to see real-life examples of the topics studied in the book and fostered the development of the student's critical thinking. One student stated:

"The newspaper articles were interesting; they helped me to make correlations between the theory and real-life situations. However, it took a lot of time to read them.

Another student observed:

"The funny and absurd real-world situations described in the newspaper articles facilitated the learning of the systemic problems."

The analysis of the answers to the Q4 led us to our fourth recurrent theme:

RT4- The newspaper articles illustrated the theory very well.

Analyzing the answers to Q5, we may say that most of the students expressed that the documentaries were important to their learning because they were complementary to the book's topics. They also stressed that majority of documentaries were interesting, helping them to make correlations between theory and real-life situations. They also acknowledged that the movies made clear the connections between the parts of complex systems, the interdependencies. One student pointed out:

"The documentaries were of great importance for the understanding the course's topics, they were very complementary to the course's readings."

Another student observed:

"The documentaries allowed us to see the systemic aspect of problems in details"

The analysis of the answers to Q5 led us to our fifth recurrent theme:

RT5- The movies facilitated the understanding of the hidden structures of complex systems.

Analyzing the answers to Q6, we may say that many students enjoyed the experience of reading poetry. One student observed:

"This is the first course that brings poetry to the students. I simply loved it!"

Another student stated:

"I liked the poems; they promoted learning through awareness-raising, helping to fix content."

The analysis of the answers to the Q6 led us to our sixth recurrent theme:

RT6- Poetry engaged student's emotions during the learning process. 
Analyzing the answers to Q7, we may say the majority of students liked the songs, found them interesting and made the learning more enjoyable. One student pointed:

"The songs had a similar effect as poetry: they bring emotions to the learning process".

Another student explained:

"Learning with songs was the best part of the course!"

The analysis of the answers to the Q7 led us to our seventh recurrent theme:

RT7- Songs made the learning process more enjoyable.

Analyzing the answers to Q8, we may say the students liked stories, found them interesting, funny and instructive, easy to understand and relevant to the book chapters. They also pointed out that the stories fostered their critical thinking,

One student stated:

"It took time to read the stories; however, it helped to understand topics that were not totally clear to me, it helped to expand my way of thinking."

Another student made this reflection:

"Reading the stories helped me know the point of view of important thinkers and critics. These readings were related to the book, mainly to the case studies"

The analysis of the answers to the Q8 led us to our eighth recurrent theme:

RT8- The use of stories fostered critical thinking and reflection.

Analyzing the students' answers to Q9 we may say they liked the cases studies, which helped them to develop their modeling and critical thinking skills.

One student stated:

"The case studies were well structured, easy to understand, and they helped lot the learning process."

Another student stressed the importance of the case studies:

"The case studies had a fundamental importance in the learning. Without them the course would not make sense."

Another student stressed the importance of the hands-on approach:

"The hands-on approach of the case studies made us really learn."

The analysis of the answers to Q9 also led us to our ninth recurrent theme:

RT9- The case studies help the students to develop their modeling skills

Analyzing the students answers to Q10 we may say that the combined use of different forms of art (visual art, literature, performing arts and media arts) helped the students to have a better understanding of the concepts, aroused their curiosity, broadened their view of systemic problems, and helped to fix the contents. One student pointed out:

"Reading the book and then accessing the complementary materials helped a lot to fix the concepts studied because the materials showed real applications of what was taught."

Another student observed:

Anatolian Journal of Education, October $2018 \bullet$ Vol.3, No.2 
"I was amazed, I found it incredible to make connections between the readings and the art material in that way; I have never experienced it before. Now I can see problems and situations in a broader and deeper perspective."

One student commented:

"I think this was the most interesting part of the course, to associate everything to the world we live in, to make the connections between what I read and my real-world experiences. I liked the feelings that songs and texts aroused to me.

The analysis of the answers to the Q10 led us to our tenth recurrent theme:

RT10- The combined use of different forms of art created synergies that facilitated the learning.

Table 3 summarizes the ten recurrent themes that emerged from the application of the language process method to the open-ended questions.

Table 3

The recurrent themes

\begin{tabular}{|c|c|}
\hline \multicolumn{2}{|c|}{ Recurrent themes that emerged from the answers to the questions related to the learning environment and the textbook. } \\
\hline RT1 & The cartoon-illustrated textbook aroused interest and facilitated the comprehension. \\
\hline RT2 & The website facilitated students' ability to find the course's material. \\
\hline RT3 & $\begin{array}{l}\text { The website's comic strips and the cartoons facilitated comprehension and aroused the students' } \\
\text { interest and curiosity. }\end{array}$ \\
\hline \multicolumn{2}{|c|}{ Recurrent themes that emerged from the answers to the questions related to the connection between theory and real-life. } \\
\hline RT4 & The newspaper articles illustrated the theory very well. \\
\hline RT5 & nderstanding of the hidden structures of complex systems. \\
\hline RT6 & ons to learning process. \\
\hline RT7 & Songs made $\mathrm{t}$ \\
\hline RT8 & and reflectio \\
\hline RT9 & The case studies help the students to develop their modeling skills. \\
\hline \multicolumn{2}{|c|}{$\begin{array}{l}\text { Recurrent themes that emerged from the answers to the questions related to the students' perspective about the combined use } \\
\text { of all forms of art. }\end{array}$} \\
\hline RT 10 & The combined use of different forms of art created synergies that facilitated the learning. \\
\hline
\end{tabular}

\section{Data related to the case studies created by the students}

The students created 46 case studies in their four different areas of expertise. The case studies themes are shown in table 4; the students' grades are shown in table 5.

Table 4

The case studies created

\begin{tabular}{ll}
\hline Case study category & Case study theme \\
\hline Health sciences & $\begin{array}{l}\text { The irrational use of antibiotics, Doctor's appointment, Geriatric eye care, Self-medication, Dynamics of flu, Diet and } \\
\text { fitness, Students' depression, Social anxiety disorder. }\end{array}$ \\
Science and Technology & $\begin{array}{l}\text { Digital terrorism, Planned obsolescence, Students' difficulties in learning programming, Students' difficulties in } \\
\text { learning physics, Students' workload, Quality management. }\end{array}$ \\
$\begin{array}{l}\text { Environmental Sciences, } \\
\text { Chemistry and Pharmacy }\end{array}$ & $\begin{array}{l}\text { Recycling, Environmental policies, Landslide processes, Drug disposal, Solid waste management, Water pollution, } \\
\text { Water scarcity, Acid rain, Management of chemical waste at university, Drug development, Antibiotics resistance, } \\
\text { Generic drugs, The collapse of Easter Island, Fermentation dynamics, Nuclear Energy, Livestock impacts on the } \\
\text { environment, Dengue dynamics. }\end{array}$ \\
$\begin{array}{l}\text { Pyrian civil war and its impacts on children education, Religious wars, Student-teacher conflicts, War on drugs, } \\
\text { and Human Sciences }\end{array}$ & $\begin{array}{l}\text { Processes of hiring teachers, Black feminism, Pet abandonment, Social entrepreneurship, Campus security, Economic } \\
\text { planning, The conspiracy of 1789, Systemic corruption, Hong Kong Political System, Famine and food crises. }\end{array}$ \\
\hline
\end{tabular}


Table 5

Evaluation of the students' case studies

\begin{tabular}{lll}
\hline Grading criteria & $\begin{array}{l}\text { Number of } \\
\text { students }\end{array}$ & $\begin{array}{l}\text { Percentage (100* } \\
\text { Students/ Total of the Students)) }\end{array}$ \\
\hline $\begin{array}{l}\text { Grade 9-10: Very interesting case, with a model without any } \\
\text { representation errors. }\end{array}$ & 30 & $65 \%$ \\
$\begin{array}{l}\text { Grade 8-9: Interesting case, with a model with minor errors. } \\
\text { Grade 7-8: Case study acceptable, with a model with acceptable errors. }\end{array}$ \\
$\begin{array}{l}\text { Grade 0-7 (Student Failed: Case unacceptable, with a model with } \\
\text { unacceptable errors. }\end{array}$
\end{tabular}

\section{CONCLUSION, DISCUSSION AND SUGGESTIONS}

Regarding the textbook, the quantitative data (Table 2, line 1) suggests that all students acknowledged the book helped their learning. In addition, RT1 (The cartoon-illustrated book aroused interest and facilitated comprehension) suggests that the books' humorous illustrations indeed aroused the students' curiosity and facilitated their learning.

In relation to the website created for the course, the quantitative data (Table 2, line 2) revealed that $98 \%$ of the students considered that website organization facilitated their learning. RT2 (The wellorganized website facilitated to find the material) confirms that: the students acknowledged that they could navigate easily through the pages, finding all information they need. The quantitative data (Table 2, line 3) also suggests that $94 \%$ of the students acknowledged that the use of comic strips and cartoons in the website facilitated their learning. RT3 (The website's comics strips and the cartoons facilitated comprehension and aroused the students interest and curiosity) confirms that. Therefore, we may guess that development of comic illustrations for the website was good choice, once aroused the students' enthusiasm with the course.

In a systemic perspective, we may say that the cartoon-illustrated book and the comic-style website matched very well: their synergy created a dynamic that led to the increase in students' interest in the course (Figure 5, 'Comic drawings spark curiosity' feedback loop) and facilitated the comprehension (Figure 5, 'A picture is worth a thousand words' feedback loop). This finding is aligned with the findings of other researchers who have pointed out that comics can make the students more motivated to learn (Toh, 2009) and facilitate learning (Mallia, 2007).

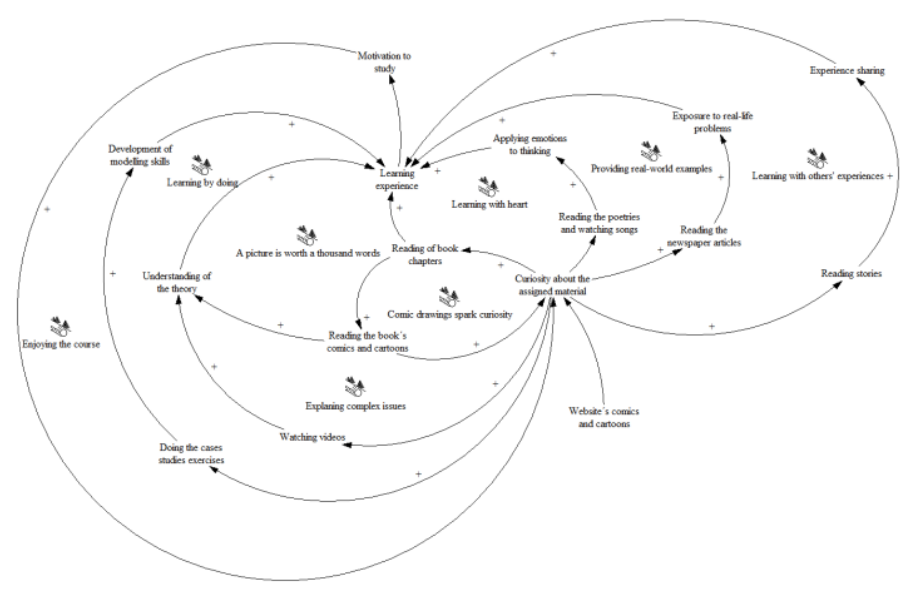

Figure 5

The systemic impacts of the techniques used 
The students also commented that the book's case studies were very useful. Ninety-seven percent of the students (Table 2, line 9) felt that the case studies facilitated their learning. RT 9 (The case studies help the students to develop their modeling skills) let us understand that challenging the students to develop models every week, in a hands-on approach, helped the students to develop their ability to create models. In a systemic interpretation, we may conjecture that the case studies generated a dynamic that led to development of the students' modeling skills, enhancing their learning experience (Figure 5, 'Learning by doing' feedback loop).

Regarding the newspaper articles, the quantitative data revealed (Table 2, line 4) that $87 \%$ of the students considered that the newspaper articles helped them to make connections between the theory and real-life situations. RT4 (The newspaper articles illustrated the theory very well) reinforces that: the voices of the students let us understand that newspaper articles gave them concrete examples of the complex dynamics present in the world. This finding is in accordance with the findings of researchers (Oliveras et al., 2013; Schaupp \& Lane, 1992) that stressed the value of using newspaper articles as an educational tool. From a systemic viewpoint, we may speculate that the use of newspaper articles improved the exposure of the students to real-life problems, which contribute to making the learning experience more meaningful (Figure 5, 'Providing real-world examples' feedback loop).

Analyzing the effects of the stories in the students' learning we may say that the quantitative data (Table 2, line 8) revealed that $87 \%$ of the students considered that the stories also helped to establish associations between theory and practice. RT8 (The use of stories fostered critical thinking and reflection) shows that the stories made the students to use their imagination, making them to reflect, to create analogies between the stories told and their theory studied. It was clear to us the stories helped the students to learn with the experiences of shared by the authors of the stories. This finding is in accordance with the findings of researchers (Hernández-Serrano \& Stefanou, 2009; Jonassen \& Hernandez-Serrano, 2002) that stressed the importance of the use of stories to foster experiences sharing. We may conjecture that the use of stories in our course improved their learning experience (Figure 5, 'Learning with others 'experiences' feedback loop).

Regarding the effects of films, the quantitative data (Table 2, line 5) revealed that $85 \%$ of the students acknowledged positive impacts in their learning. RT5 (The movies facilitated the understand the hidden structures of complex systems) let us understand that the movies allowed the students to understand the complexity present in real-life systems, and the interrelationships and the interconnections between systems parts. This finding is aligned with the findings of other researchers (Hooper et al., 2011; Mateer \& Stephenson, 2011) who point out that films may allow the comprehension of multifaceted problems. In a systemic standpoint, we may guess that films facilitated the understanding of the theory, contributing therefore to the enhancement of the students' learning experience (Figure 5, 'Explaining complex issues' feedback loop).

Analyzing the use of poetry, the quantitative data (Table 2, line 6) shows that $66 \%$ of the students thought that poetries facilitated their learning. RT6 (Poetry made the students bring emotions to learning process) points that poetry is related to emotional intelligence. This finding is in accordance with the studies of researchers (Morris et al., 2005) who point out that poetry may foster creativity. In a systemic viewpoint, we may guess that poetry contributed to the learning experience by bringing emotions to thinking (Figure 5, 'Learning with heart' feedback loop).

In regard to songs, quantitative data (Table 2, line 6) shows that although $72 \%$ of the students thought that songs facilitated their learning. RT7 (Songs made the learning process more enjoyable) let us know that songs have similar effect to the poetry, songs also brought emotions to the learning process.

But what about the students' projects? Did the projects reflect that the students learned systems thinking concepts? Data (Table 4) revealed the students were able to create very diverse case studies 
in their fields of expertise. The majority of the students, ninety-one percent (Table 5), were able to create interesting case studies and correct models.

So, what did we learn from this experience? How effective was the use of the arts in fostering the students' interest, engagement and learning in our course?"

We may answer this question by connecting the previous analysis with all feedback loops represented in Figure 5. This systemic map that allows us to reflect deeply on the combined effects of all actions we took in our course. The map makes clear the interrelationship between our actions of using the arts in our course and its effects on the learning. We may conclude saying that the use of the arts in our course was indeed very effective, impacting positively on the learning experience and on the students' engagement. The visual arts (comic strips and cartoons) presented in the course website and in the book sparked the students' curiosity, making them interested in exploring all course material. It is interesting to note that each form of art contributed to the learning in a complementary way. The documentaries, case studies, and newspaper articles stimulated critical thinking and logical reasoning. In complement to that, poetry, songs and stories stimulated the imagination and the creativity. We may consider that such rich learning experience stimulated the students' motivation to study and increased their curiosity about the use of system thinking in their fields of study. The analysis of all qualitative and quantitative data made clear that all material helped the students to make connections between theory and practice. The quality of the students' projects reflected the students had in fact learned systems thinking concepts and apply them in their field of expertise.

Finally, we may say that the use of music, poetry, stories and films helped students to make connections between theory and practice, thereby improving their learning. We can also affirm that students' use of these materials also increased their enthusiasm for the course. We also found that the visual arts fostered the students' curiosity, increasing their engagement in the proposed activities.

We hope this article may be of interest of other researchers interested in the use of the arts in their courses. For further information, we invite readers to visit the course's website ( http://www.systemdynamics.com.br/)

\section{REFERENCES}

Arantes do Amaral, J.A. (2012). Desvendando Sistemas [Unveiling Systems]. São Paulo, SP: Editora Arantes.

Arantes do Amaral, J. A., Gonçalves, P., \& Hess, A. (2015). Creating a Project-Based Learning Environment to Improve Project Management Skills of Graduate Students. Journal of Problem Based Learning in Higher Education, 3(2), 120-130.

Arantes do Amaral, J. A., Frazão, C. (2016). The Systemic Impacts of An Educational Project Conducted by One University in Partnership with Fifteen Organizations. Science Education International, 27(3), 391-418.

Arantes do Amaral, J. A., Hess, A., Gonçalves, P., \& Rodrigues, V. P. (2017). Using Group Drawings Activities to Facilitate the Understanding of the Systemic Aspects of Projects. International Journal of Instruction, 10(2), 3-22.

Bauman, Y., \& Klein , G. (2011). The Cartoon Introduction to Economics: Volume Two: Macroeconomics. New York, NY: Hill and Wang.

Bauman, Y., \& Klein, G. (2014). The Cartoon Introduction to Climate Change. Washington, DC: Island Press. 
Bauman, Y., Klein, G. (2010). The Cartoon Introduction to Economics: Volume One: Microeconomics. New York, NY: Hill and Wang.

Bumpus, M. A. (2005). Using motion pictures to teach management: Refocusing the camera lens through the infusion approach to diversity. Journal of Management Education, 29(6), 792-815.

Çetinavc1, U. R., \& Tütüniş, B. (2012). Making use of poems to teach English. The Journal of Language Teaching and Learning, 2(2), 75-88.

Charon, R., Banks, J. T., Connelly, J. E., Hawkins, A. H., Hunter, K. M., Jones, A. H., Poirer, S. (1995). Literature and medicine: contributions to clinical practice. Annals of Internal Medicine, 122(8), 599-606.

Creswell, J. W. (2013). Research design: Qualitative, quantitative, and mixed methods approaches. Thousands Oaks, CA: Sage publications.

Curry, L., \& Nunez-Smith, M. (2014). Mixed methods in health sciences research: A practical primer. Thousands Oaks, CA: Sage Publications.

Decker, A. C., \& Castro, M. (2012). Teaching history with comic books: A case study of violence, war, and the graphic novel. The History Teacher, 45(2), 169-187.

Driscoll, D. L., Appiah-Yeboah, A., Salib, P., \& Rupert, D. J. (2007). Merging qualitative and quantitative data in mixed methods research: How to and why not. Ecological and Environmental Anthropology (University of Georgia), 3(1), 19-28.

Freeman, L. H., \& Bays, C. (2007). Using literature and the arts to teach nursing. International Journal of Nursing Education Scholarship, 4(1), 1-14.

Gonick, L.,\& Huffman A. (1991). The cartoon guide to physics. New York, NY: Harper Collins.

Gonick, L. (2012). The cartoon guide to calculus. New York, NY: William Morrow.

Gonick, L. (2015). The cartoon guide to algebra. New York, NY: William Morrow.

Gonick, L., \& Outwater, A. (1996). The cartoon guide to the environment. New York, NY: Harper Collins.

Gonick, L., \& Smith, W. (1993). The cartoon guide to statistics. New York, NY: Harper Collins.

Gonick, L., \& Wheelis, M. (1991). Cartoon guide to genetics. New York, NY: Harper Perennial.

Graham, A., Shiba, S., \& Walden, D. (2001). Four practical revolutions in management: Systems for creating unique organizational capability. Boca Raton, FL: CRC Press.

Hall, J. (2005). Homer Economicus: Using The Simpsons to Teach Economics. Journal of Private Enterprise, 1(1), 165-176.

Hall, J., \& Lawson, R. A. (2008). Using music to teach microeconomics. Perspectives in Economic Education Research, 4(1), 23-36.

Hernández-Serrano, J., \& Stefanou, S. E. (2009). Knowledge at work: learning and transferring expert reasoning through storytelling. Education, Knowledge \& Economy, 3(1), 55-80.

Hooper, R., Lilienfeld, L., \& Arrigo, J. (2011). Using documentaries for Earth science education. Eos, Transactions American Geophysical Union, 92(42), 361-362. 
Jonassen, D. H., \& Hernandez-Serrano, J. (2002). Case-based reasoning and instructional design: Using stories to support problem solving. Educational Technology Research and Development, 50(2), 65-77.

Kunselman, J. C., \& Johnson, K. A. (2004). Using the case method to facilitate learning. College Teaching, 52(3), 87-92.

Leet, D., \& Houser, S. (2003). Economics goes to Hollywood: Using classic films and documentaries to create an undergraduate economics course. The Journal of Economic Education, 34(4), 326-332.

Lindvang, C., \& Beck, B. (2015). Problem Based Learning as a Shared Musical Journey-Group Dynamics, Communication and Creativity. Journal of Problem Based Learning in Higher Education, 3(1), 1-19.

Mallia, G. (2007). Learning from the sequence: The use of comics in instruction. ImageTexT: $\begin{array}{lllll}\text { Interdisciplinary } & \text { Comics } & \text { Studies, } & \text { 3(3) from }\end{array}$ http://www.english.ufl.edu/imagetext/archives/v3_3/mallia/

Marcus, A. S., \& Stoddard, J. D. (2009). The inconvenient truth about teaching history with documentary film: Strategies for presenting multiple perspectives and teaching controversial issues. The Social Studies, 100(6), 279-284.

Mateer, G. D., \& Stephenson, E. F. (2011). Using film clips to teach public choice economics. Journal of Economics and Finance Education, 10(1), 28-36.

Mayo, J. A. (2004). Using case-based instruction to bridge the gap between theory and practice in psychology of adjustment. Journal of Constructivist Psychology, 17(2), 137-146.

Morris, J. A., Urbanski, J., \& Fuller, J. (2005). Using poetry and the visual arts to develop emotional intelligence. Journal of Management Education, 29(6), 888-904.

Mysliwiec, T. H., Shibley Jr, I., \& Dunbar, M. E. (2003). Using newspapers to facilitate learning. Journal of College Science Teaching, 33(3), 24.

Nitta, H., \& Takatsu, K. (2009). The manga guide to physics. San Francisco, CA: No Starch Press.

Oliveras, B., Márquez, C., \& Sanmartí, N. (2013). The use of newspaper articles as a tool to develop critical thinking in science classes. International Journal of Science Education, 35(6), 885-905.

Popil, I. (2011). Promotion of critical thinking by using case studies as teaching method. Nurse education today, 31(2), 204-207.

Ramos, P., \& Vergueiro, W. (2013). Quadrinhos na educação [Comics in Education]: São Paulo, SP: Editora Contexto.

Renner, M., \& Taylor-Powell, E. (2003). Analyzing qualitative data. Programme Development \& Evaluation, University of Wisconsin-Extension Cooperative Extension.Retrieved from https://pdfs.semanticscholar.org/8ee4/a0c8532720200bb4359cf5a3741fac60ca74.pdf

Richie, J. (1979). The funnies aren't just funny: Using cartoons and comic strips to teach.Clearing House. 53(3), 125-128.

Scanlan, S. J., \& Feinberg, S. L. (2000). The cartoon society: Using "The Simpsons" to teach and learn sociology. Teaching Sociology. 28(2),127-139.

Schaupp, D. L., \& Lane, M. S. (1992). Teaching business ethics: Bringing reality to the classroom. Journal of Business Ethics, 11(3), 225-229. 
Takahashi, S. (2008). The manga guide to statistics. San Francisco, CA: No Starch Press.

Takahashi, S., \& Inoue, I. (2012). The manga guide to linear algebra. San Francisco, CA: No Starch Press.

Tatalovic, M. (2009). Science comics as tools for science education and communication: a brief, exploratory study. Journal of Science Communication, 8(4), 1-17.

Thorsted, A. C., Bing, R. G., \& Kristensen, M. (2015). Play as mediator for knowledge-creation in Problem Based Learning. Journal of Problem Based Learning in Higher Education, 3(1), 63-77.

Tinari, F. D., \& Khandke, K. (2000). From rhythm and blues to Broadway: Using music to teach economics. The Journal of Economic Education, 31(3), 253-270.

Toh, T. L. (2009). Use of cartoons and comics to teach algebra in mathematics classrooms. Mathematics Of Prime Importance, 1(1), 230-239.

Watson, C. E. (2003). Using stories to teach business ethics-developing character through examples of admirable actions. Teaching Business Ethics, 7(2), 93-105.

Yin, R. K. (2015). Qualitative research from start to finish: New York, NY: Guilford Publications.

APPENDIX 1- QUERIES ABOUT LEARNING

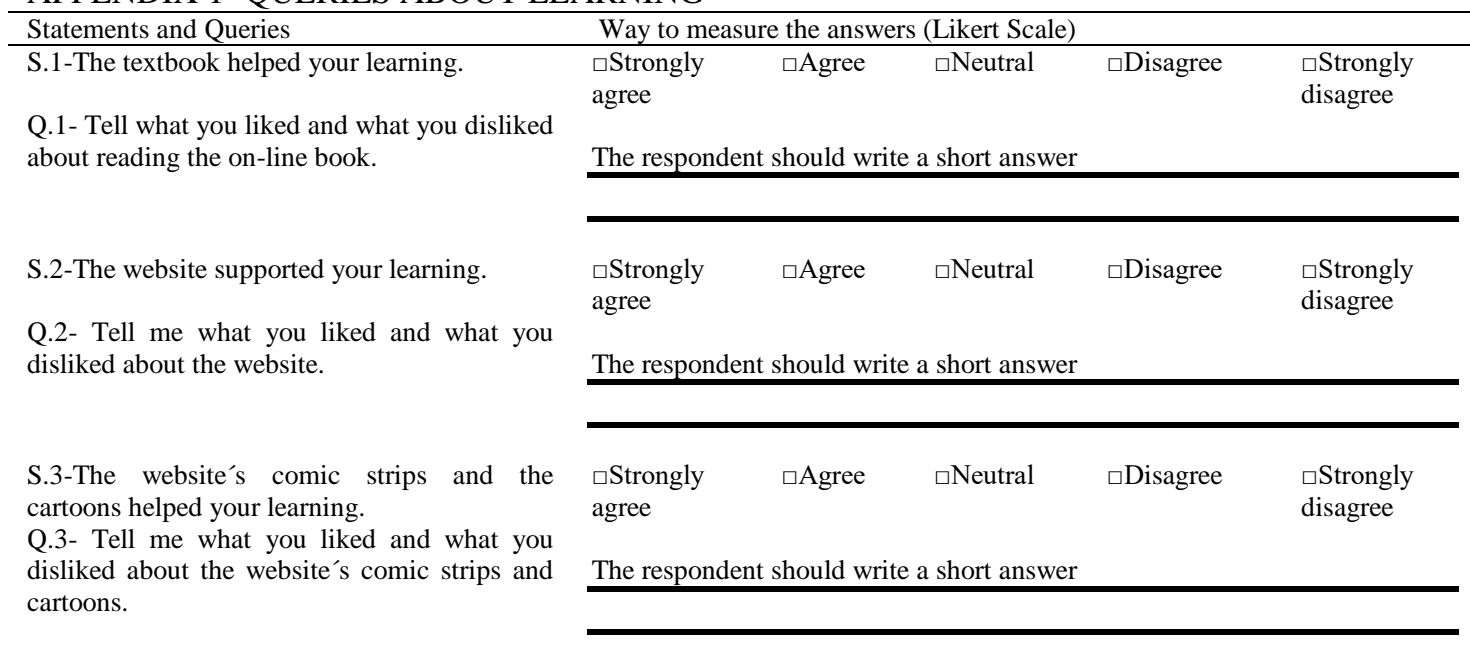

APPENDIX 2- QUERIES ABOUT CONNECTING THEORY AND REAL-LIFE PROBLEMS

\begin{tabular}{|c|c|c|c|c|}
\hline Statements and Queries & Way to measure the ans & (Likert Sc & & \\
\hline $\begin{array}{l}\text { S.4-The newspaper articles helped you to make } \\
\text { connections between the theory and real-life } \\
\text { problems. } \\
\text { Q.4- Tell me what you liked and what you } \\
\text { disliked about the newspaper articles. }\end{array}$ & $\begin{array}{l}\square \text { Strongly } \quad \square \text { Agree } \\
\text { agree }\end{array}$ & $\square$ Neutral & $\square$ Disagree & $\begin{array}{l}\square \text { Strongly } \\
\text { disagree }\end{array}$ \\
\hline $\begin{array}{l}\text { S.5-The videos (documentaries, interviews and } \\
\text { speeches) helped you to make connections }\end{array}$ & $\begin{array}{l}\square \text { Strongly } \\
\text { agree }\end{array}$ & $\square$ Neutral & $\square$ Disagree & $\begin{array}{l}\square \text { Strongly } \\
\text { disagree }\end{array}$ \\
\hline
\end{tabular}

Anatolian Journal of Education, October $2018 \bullet$ Vol.3, No.2 


\begin{abstract}
between the theory and real-life problems.
Q.5- Tell me what you liked and what you disliked about the videos (documentaries and films).

S.6-The poetry helped you to make connections between the theory and real-life problems.

Q.6- Tell me what you like and what you dislike about the poetries.
\end{abstract}

S.7-The songs helped you to make connections between the theory and real-life problems.

Q.7- Tell me what you liked and what you disliked about the songs.

S.8-The stories helped you to make connections between the theory and real-life problems.

Q.8- Tell me what you liked and what you disliked about the stories.

S.9-The case studies helped you to make connections between the theory and real-life problems.

Q.9- Tell me what you liked and what you disliked about the case studies.
The respondent should write a short answer

\begin{tabular}{|c|c|c|c|c|}
\hline $\begin{array}{l}\square \text { Strongly } \\
\text { agree }\end{array}$ & $\square$ Agree & $\square$ Neutral & $\square$ Disagree & $\begin{array}{l}\square \text { Strongly } \\
\text { disagree }\end{array}$ \\
\hline \multicolumn{5}{|c|}{ The respondent should write a short answer } \\
\hline $\begin{array}{l}\square \text { Strongly } \\
\text { agree }\end{array}$ & $\square$ Agree & $\square$ Neutral & $\square$ Disagree & $\begin{array}{l}\square \text { Strongly } \\
\text { disagree }\end{array}$ \\
\hline
\end{tabular}

\begin{tabular}{|c|c|c|c|c|}
\hline $\begin{array}{l}\square \text { Strongly } \\
\text { agree }\end{array}$ & $\square$ Agree & $\square$ Neutral & $\square$ Disagree & $\begin{array}{l}\square \text { Strongly } \\
\text { disagree }\end{array}$ \\
\hline \multicolumn{5}{|c|}{ The respondent should write a short answer } \\
\hline $\begin{array}{l}\square \text { Strongly } \\
\text { agree }\end{array}$ & $\square$ Agree & $\square$ Neutral & $\square$ Disagree & $\begin{array}{l}\square \text { Strongly } \\
\text { disagree }\end{array}$ \\
\hline
\end{tabular}

The respondent should write a short answer

APPENDIX 3- QUESTIONS ABOUT THE STUDENTS' PERSPECTIVES ON THE COMBINED USE OF ALL FORMS OF ART

\begin{tabular}{ll}
\hline Questions & The respondent should write a short answer \\
\hline Q.10- Tell me about your experience of reading a book \\
chapter and then trying to connect the content with \\
music, poetry, stories, documentaries and newspaper \\
reports.
\end{tabular}

